\title{
INTRA-RING COMPRESSION STRENGTH OF LOW DENSITY HARDWOODS
}

\author{
Audrey Zink-Sharp and Carlile Price
}

\author{
In memoriam of Dr. Walter G. KAUMAN
}

\begin{abstract}
Engineered wood composites are being crafted with increasingly smaller and smaller components, yet a search of the literature indicates a lack of intra-ring mechanical property data for almost all commercial wood types, particularly the underutilized low density hardwoods. In addition, there is no universally accepted testing regime for determining micromechanical properties of wood samples. As a result, we developed a testing system for determining compression, tension, and bending properties of growth ring regions of wood samples. Our microtesting system consists of a $45.4 \mathrm{~kg}$ load stage, motor drive, data acquisition system, motor control, load cell, strain transducer, and software. In this study, intra-ring compression strength parallel to the grain was determined for small samples (a few $\mathrm{ml}^{3}$ in volume) of sweetgum (Liquidambar styraciflua), yellow-poplar (Liriodendron tulipifera), and red maple (Acer rubrum). It was determined that compression strength is weakly correlated with specific gravity but unrelated to growth rate. Specific gravity was also unrelated to growth rate. Sweetgum values were intermediate between yellow-poplar and red maple.
\end{abstract}

Keywords: Compression strenght; specific gravity; growth rate; intra-ring mechanical properties.

\section{INTRODUCTION}

Research on the mechanical properties of wood on the micro-scale has received more widespread emphasis recently due to the dramatic upsurge in genetic and wood quality research that seek to modify wood properties at a very basic level. Effectiveness of the modifications can be accurately and rapidly determined at the intra-ring property level. In addition, an understanding of intra-ring mechanical properties is required for complete characterization of the interrelationships within wood's hierarchical structure. For example, determination of intra-ring properties provides knowledge of the limits for a particular property under study.

Due to the complexity of wood's heterogeneous, anisotropic nature, theoretical and mathematical models abound for prediction of various physical properties. Micro-mechanical test results can serve as important verification and confirmation for the various models.

Trees have the ability to make minute variations to cell wall architecture in response to external stimuli that dramatically alter the overall mechanical properties. These slight changes in intra-ring properties propagate to the higher levels of wood structure and influence the macroscopic behavior, and ultimately, wood utilization. Thus, it becomes obvious that a better understanding of wood demands micro-mechanical investigations at the growth ring level.

A search of the literature indicates a lack of intra-ring mechanical property data for almost all commercial wood types, particularly the underutilized low density hardwoods. As well, there is no

Wood Science and Forest Products 230 Cheatham Hall Virginia Polytechnic Institute and State University

Blacksburg, Virginia USA

agzink@vt.edu,cprice@vt.edu

Corresponding author: agzink@vt.edu

Received: December 21, 2005. Accepted: May 27, 2006. 
universally accepted testing regime for determining micro-mechanical properties of wood samples. Consequently, we developed a testing system for determining compression, tension, and bending properties of growth ring regions of wood samples. Earlier micro-mechanical testing of wood focused primarily on individual wood fibers due to the interest in paper manufacture (Ehrnrooth and Kolseth 1984). More recent studies are concentrating on fracture and failure modes at the cellular level (Vasic et al. 2002 and Fruhmann et al. 2003 ) and utilizing small specimens to determine intra-ring properties (Zink-Sharp et al. 1999 and Dumail and Salmen 2001).

In this study, intra-ring compression strength parallel to the grain was determined for sweetgum (Liquidambar styraciflua), yellow-poplar (Liriodendron tulipifera), and red maple (Acer rubrum). These wood types were chosen because they are available in large supply, yet they remain underutilized presently. With a better understanding of their intra-ring properties, it will be possible to improve their utilization in wood-based composites, while at the same time, determine their interchangeability.

\section{MATERIALS AND METHODS}

Test specimens were prepared from two different sources - sawn lumber and tree cores. Sawn lumber obtained from a local sawmill provided specimens of sweetgum, yellow-poplar, and soft maple (exact species is unknown). However, only red maple (Acer rubrum) tree cores were available for specimen preparation at the time of this writing. The woods chosen for this study are all diffuse porous woods whose vessels exhibit little or no variation in size or distribution throughout the growth ring, therefore there is no distinct earlywood-latewood regions within a given growth ring. Target dimension for all specimens was 1-mm x 1-mm in cross section and 4-mm along the grain. Depending on growth ring width, this size specimen works well for intra-ring samples for most tree types, and because the aspect ratio is small, we can insure minimization of column buckling. Individual growth rings were removed from the lumber with a band saw. Compression specimens were cut from the growth rings with the single arbor press described below. Thirty compression specimens were tested for each of the three species studied.

Selected growth rings were isolated from the maple tree cores using a single arbor press equipped with a single-edge razor blade. The press fixture was used, first, to cut the selected rings from the core, and then, to remove the outer edges of the round disk where any damage and compaction from coring might have occurred. The squared disks were then examined with a light microscope to determine grain direction so that the test specimens could be cut perfectly parallel to the grain. A new razor blade is used for each growth ring to minimize any crushing and tearing, and because specimens are cut from fresh, moist tree cores, damage during preparation is kept very minimal. The press was also used to cut the specimens to their final size. Because soft maples are diffuse porous woods with no marked earlywoodlatewood regions, test specimens were centered in the growth ring. Extreme care in cutting was taken to insure that both end surfaces were parallel with each other and perpendicular to the long axis of the specimen. A fixture was fabricated for the press table to guarantee specimen geometry.

Random growth rings were selected for specimen preparation from the sawn lumber, but specimens were taken from every $10^{\text {th }}$ ring for the maple tree cores. One core was taken from three live, mature red maple trees located in the natural forested highlands of southeastern USA. Cores were $12.5 \mathrm{~mm}$ in diameter and bored through the pith from bark to bark at $1.37 \mathrm{~m}$ height from tree base. An average of 10 test specimens was cut from each selected growth ring. Table 1 below indicates details for the maple tree core specimens.

Highly sensitive measurement instruments (a caliper and analytical balance) were used to determine specimen dimensions and weight prior to and following testing. Specimens were conditioned to a uniform moisture content of $12 \%$ in a standard moisture conditioning chamber prior to testing. After compression testing, the specimens were ovendried and reweighed. Moisture content (MC) was calculated 
on the dry weight basis and specific gravity (relative density) as ovendry weight divided by volume at test, divided by $1 \mathrm{~g} / \mathrm{cm}^{3}-$ (the density of water).

Table 1. Data for test specimens from red maple tree cores

\begin{tabular}{|c|c|c|c|}
\hline \multicolumn{4}{|c|}{$\begin{array}{c}\text { Mount Rogers } \\
\text { Tree Diameter at } 1.37 \mathrm{~m} \text { from tree base }=236 \mathrm{~mm} \\
55 \text { rings in core (one side) }\end{array}$} \\
\hline Ring \# & $\begin{array}{l}\text { Distance from } \\
\text { pith to ring } \\
(\mathrm{mm})\end{array}$ & $\begin{array}{l}\text { Ring width } \\
\text { (mm) }\end{array}$ & $\begin{array}{c}\mathrm{mm} \\
\text { growth/decade }\end{array}$ \\
\hline 10 & 15 & 1 & 15 \\
\hline 20 & 38 & 2 & 23 \\
\hline 30 & 63 & 2 & 25 \\
\hline 40 & 88 & 2 & 25 \\
\hline 50 & 112 & 1.5 & 24 \\
\hline \multicolumn{4}{|c|}{$\begin{array}{l}\text { Round Mountain } \\
\text { meter at } 1.37 \mathrm{~m} \text { from tree base }=412 \mathrm{~mm} \\
70 \text { rings in core }\end{array}$} \\
\hline Ring \# & $\begin{array}{l}\text { Distance from } \\
\text { pith to ring } \\
(\mathrm{mm})\end{array}$ & $\begin{array}{l}\text { Ring width } \\
\text { (mm) }\end{array}$ & $\begin{array}{c}\mathrm{mm} \\
\text { growth/decade }\end{array}$ \\
\hline 10 & 27 & 2 & 27 \\
\hline 20 & 53 & 3 & 26 \\
\hline 30 & 90 & 4 & 37 \\
\hline 40 & 122 & 3 & 32 \\
\hline 50 & 155 & 2 & 33 \\
\hline 60 & 175 & 3 & 20 \\
\hline \multicolumn{4}{|c|}{$\begin{array}{c}\text { Reynolds Homestead } \\
\text { Tree Diameter at } 1.37 \mathrm{~m} \text { from tree base }=376 \mathrm{~mm} \\
63 \text { rings in core }\end{array}$} \\
\hline Ring \# & $\begin{array}{l}\text { Distance from } \\
\text { pith to ring } \\
(\mathrm{mm})\end{array}$ & $\begin{array}{l}\text { Ring width } \\
\text { (mm) }\end{array}$ & $\begin{array}{c}\mathrm{mm} \\
\text { growth/decade }\end{array}$ \\
\hline 10 & 35 & 1.5 & 35 \\
\hline 20 & 63 & 2 & 28 \\
\hline 30 & 105 & 1.5 & 42 \\
\hline 40 & 140 & 2 & 35 \\
\hline 50 & 162 & 2 & 22 \\
\hline
\end{tabular}

Micro-mechanical testing requires very specialized, sensitive equipment. The system developed for our study was a Fullam No. 18200 series 45.4 kg testing frame equipped with Fullam No. 18234 data acquisition software (Ernest F. Fullam, Inc, Latham, NY, USA). Figure 1 illustrates the system components, which are the testing carriage (frame), load cell, motor control, strain transducer, and data acquisition and control software module. A personal computer is also required for automated motor 
control and data acquisition. A plastic enclosure (not shown in Figure 1) surrounded the text fixture during testing to minimize moisture fluctuation. Configuration and application of our test system is more fully described in Zink-Sharp and Price (2004).

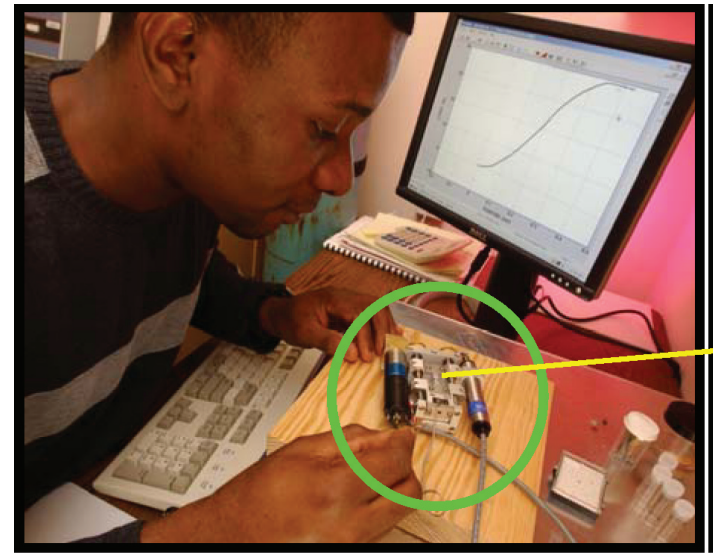

(a)

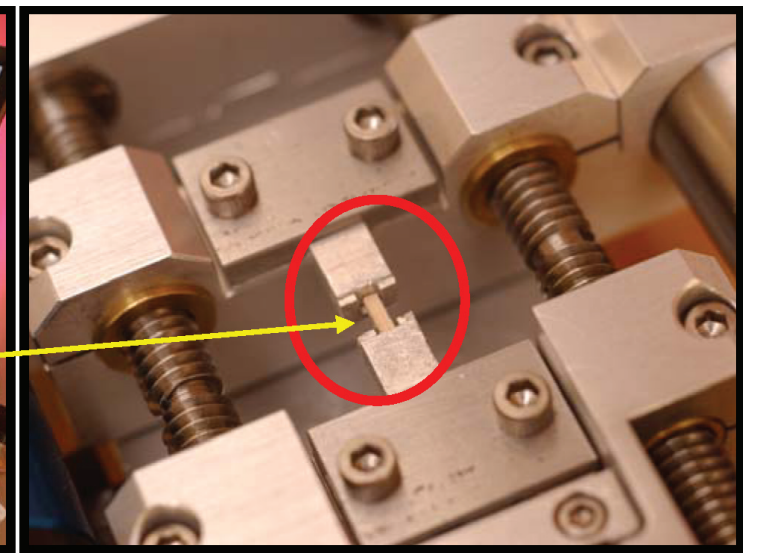

(b)

Figure 1. Micro-mechanical test system. (a) test frame (in circle), (b) compression specimen in place (circle).

Figure 1a illustrates the load frame, which measures $115 \mathrm{~mm}$ long x $100 \mathrm{~mm}$ wide x $40 \mathrm{~mm}$ high. This particular system can be used on the bench top as well as in an AMRAY 1810D or 3100 Scanning Electron Microscope (SEM). It is capable of testing tension, compression, bending, and cyclic properties. A load rate of $0.029 \mathrm{~mm} / \mathrm{min}$ was used to produce a continuous and uniform load rate. A slight preload $(0.5 \mathrm{~N})$ was imposed on the specimens to ensure contact with the load faces and minimize shifting during loading. One side of load apparatus was allowed to float and this also aided in minimizing misalignment during loading. Figure $1 \mathrm{~b}$ illustrates the compression specimen in place prior to load application.

Maximum compression stress - MCS (also known as crushing strength) was calculated by the data acquisition software and reported on load/position plots. The equation used was:

$$
\sigma=P / A
$$

where $\sigma=$

$$
\begin{array}{ll}
\mathrm{P} & = \\
\mathrm{A} & =
\end{array}
$$

peak compression stress $(\mathrm{kPa})$

peak load (Newtons)

cross sectional area $\left(\mathrm{m}^{2}\right)$

\section{RESULTS AND DISCUSSION}

A summary of test results for specimens from the lumber is shown in Table 2 below. The number of test specimens is indicated in brackets [ ] and the standard deviation in parentheses ( ). 
Table 2. Data for intra-ring specimens taken from lumber.

\begin{tabular}{|l|c|c|c|}
\hline & SG & MC (\%) & $\begin{array}{c}\text { Max Compression } \\
\text { Stress (MPa) }\end{array}$ \\
\hline yellow-poplar [30] & 0.44 & 12.2 & 33.5 \\
& $(0.04)$ & $(0.6)$ & $(4.9)$ \\
\hline sweetgum [30] & 0.48 & 12.4 & 39.2 \\
& $(0.03)$ & $(0.5)$ & $(3.5)$ \\
\hline soft maple [30] & 0.51 & 11.9 & 41.6 \\
& $(0.03)$ & $(0.6)$ & $(4.8)$ \\
\hline
\end{tabular}

To further investigate the relationship between specific gravity and strength, Figure 2 was prepared using all 90 data points from the 90 hardwood specimens. Notice that sweetgum values fall intermediate between yellow-poplar on the low end and soft maple on the high end, and that sweetgum overlaps the red maple more than the yellow-poplar. When taken as a group, an upward trend in strength with increased specific gravity is noticeable in Figure 2.

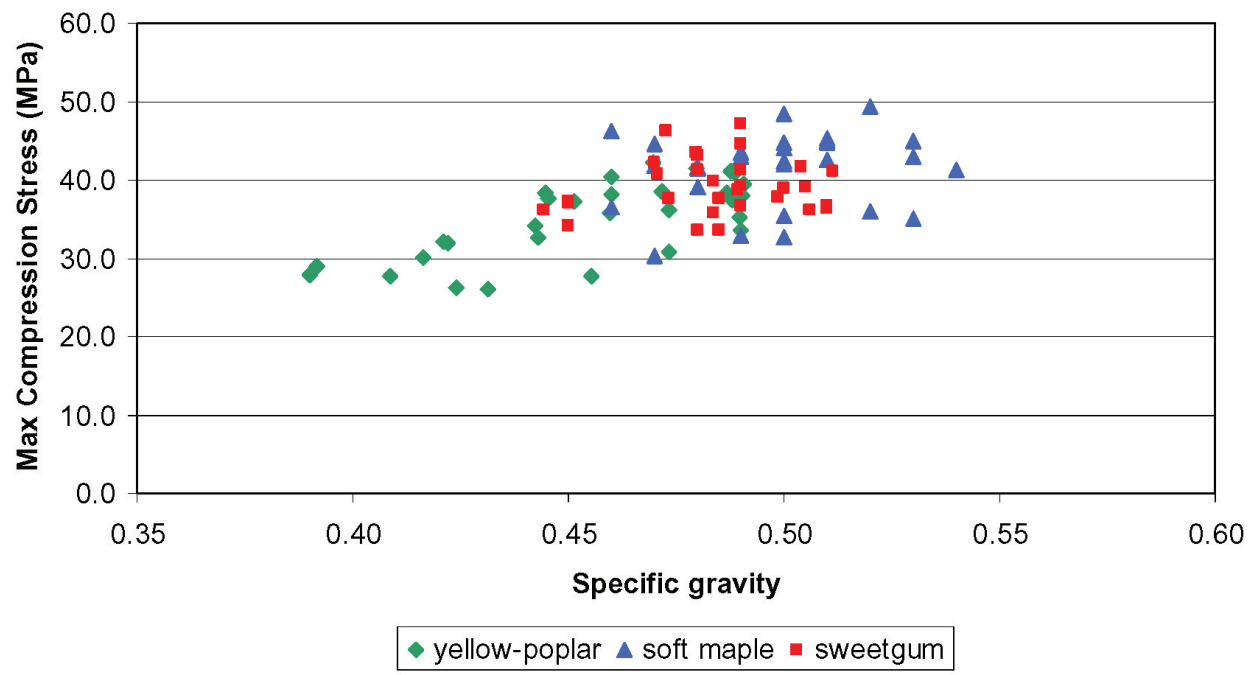

Figure 2. Maximum compression stress versus specific gravity for intra-ring specimens taken from sawn lumber.

A summary of test results for specimens from the maple tree cores is shown in Table 3, below. The number of test specimens is indicated in brackets [ ] and the standard deviation in parentheses ( ). Examination of Table 3 indicates remarkably little variation across the diameter of the three trees, each taken from a different location. Neither the specific gravity nor the average strength values are statistically significantly different amongst the three trees.

Figure 3 indicates the relationship between compression strength and specific gravity for all maple core test specimens. As expected, an increasing trend in strength with increased specific gravity is noticeable in Figure 3. However, the cofficient of determination $\left(\mathrm{r}^{2}\right)$ is only 0.49 and significant at a $95 \%$ confidence level. 
Figure 3. Maximum compression stress versus specific gravity for intra-ring specimens taken from the maple tree cores.

\begin{tabular}{|c|c|c|c|c|c|}
\hline \multicolumn{6}{|c|}{ Mt. Rogers [43] } \\
\hline ring \# & $\begin{array}{l}\text { \# specimens/ } \\
\text { ring }\end{array}$ & SG & $\mathrm{MC}(\%)$ & $\begin{array}{c}\text { Max. } \\
\text { Compression } \\
\text { Stress }(\mathrm{MPa})\end{array}$ & $\begin{array}{l}\text { Max. Load } \\
\text { (N) }\end{array}$ \\
\hline 10 & 10 & $0.57(0.04)$ & $10.1(3.1)$ & $28.3(3.3)$ & $30.6(3.0)$ \\
\hline 20 & 8 & $0.56(0.03)$ & $8.7(2.2)$ & $28.0(1.6)$ & $31.4(1.4)$ \\
\hline 30 & 7 & $0.57(0.03)$ & $11.1(1.1)$ & $31.4(2.0)$ & $37.9(4.3)$ \\
\hline 40 & 9 & $0.64(0.05)$ & $10.1(1.7)$ & $31.6(1.6)$ & $27.3(4.2)$ \\
\hline 50 & 9 & $0.61(0.01)$ & $10.5(2.9)$ & $29.9(3.0)$ & $30.5(3.7)$ \\
\hline & average & $0.59(0.04)$ & $10.1(2.4)$ & $29.8(2.8)$ & $30.6(5.0)$ \\
\hline \multicolumn{6}{|c|}{ Round Mountain [56] } \\
\hline ring \# & $\begin{array}{l}\text { \# samples/ } \\
\text { ring }\end{array}$ & SG & $\mathrm{MC}(\%)$ & $\begin{array}{c}\text { Max. } \\
\text { Compression } \\
\text { Stress (MPa) }\end{array}$ & $\begin{array}{l}\text { Max. Load } \\
\text { (N) }\end{array}$ \\
\hline 10 & 9 & $0.60(0.02)$ & $12.1(0.9)$ & $29.6(3.5)$ & $33.9(4.6)$ \\
\hline 20 & 8 & $0.59(0.03)$ & $11.4(2.3)$ & $30.5(3.5)$ & $32.2(5.8)$ \\
\hline 30 & 9 & $0.59(0.03)$ & $14.2(2.4)$ & $25.7(3.9)$ & $24.6(3.5)$ \\
\hline 40 & 10 & $0.62(0.02)$ & $10.1(2.1)$ & $29.0(6.2)$ & $32.4(6.3)$ \\
\hline 50 & 10 & $0.61(0.03)$ & $11.3(1.6)$ & $26.4(3.1)$ & $33.2(6.0)$ \\
\hline 60 & 10 & $0.61(0.04)$ & $12.4(2.5)$ & $30.1(3.8)$ & $31.9(6.4)$ \\
\hline & average & $0.60(0.03)$ & $11.8(2.5)$ & $28.2(4.5)$ & $30.9(6.4)$ \\
\hline \multicolumn{6}{|c|}{ Reynolds Homestead [49] } \\
\hline ring \# & $\begin{array}{l}\text { \# samples/ } \\
\text { ring }\end{array}$ & SG & $\mathrm{MC}(\%)$ & $\begin{array}{c}\text { Max. } \\
\text { Compression } \\
\text { Stress (MPa) }\end{array}$ & $\begin{array}{l}\text { Max. Load } \\
\text { (N) }\end{array}$ \\
\hline 10 & 10 & $0.68(0.02)$ & $11.4(1.3)$ & $33.2(3.7)$ & $34.4(5.2)$ \\
\hline 20 & 9 & $0.57(0.04)$ & $12.2(2.2)$ & $27.5(4.6)$ & $31.9(7.6)$ \\
\hline 30 & 10 & $0.62(0.05)$ & $9.5(1.1)$ & $30.7(5.4)$ & $29.6(6.7)$ \\
\hline 40 & 10 & $0.61(0.03)$ & $11.0(2.5)$ & $26.9(5.3)$ & $28.0(5.5)$ \\
\hline \multirow[t]{2}{*}{50} & 10 & $0.60(0.02)$ & $9.8(0.7)$ & $28.0(5.1)$ & $31.9(5.9)$ \\
\hline & average & $0.61(0.05)$ & $10.6(1.9)$ & $29.4(5.0)$ & $31.1(6.2)$ \\
\hline $\begin{array}{c}\text { overall } \\
\text { average }\end{array}$ & $\begin{array}{c}148 \\
\text { specimens }\end{array}$ & $0.60(0.04)$ & $10.8(2.3)$ & $29.1(4.1)$ & $30.9(5.9)$ \\
\hline
\end{tabular}




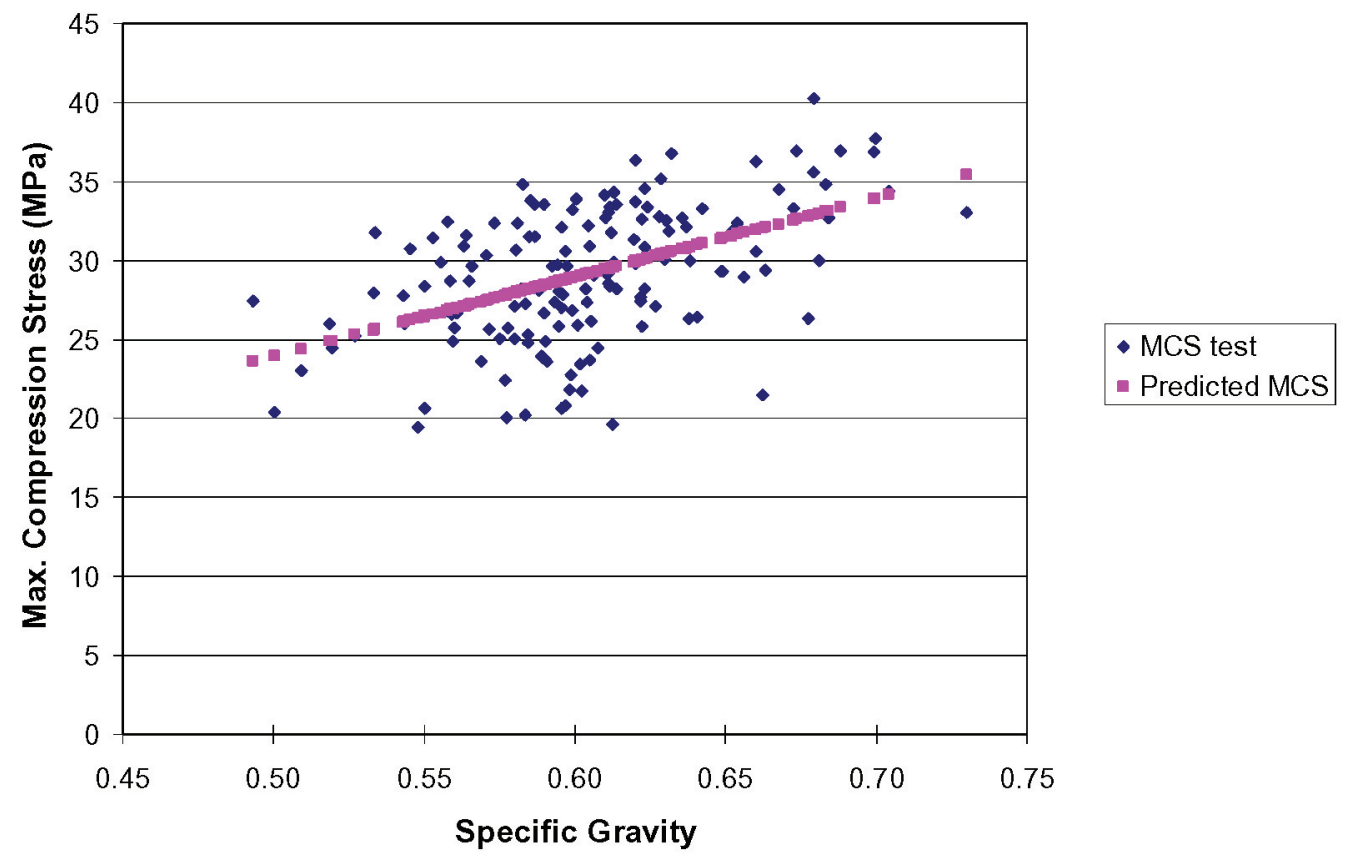

With ring porous and most softwoods, changes in growth rate usually induce changes in growth ring width and subsequent wood properties (Bendtsen 1978, Biblis et al. 1995, Hernández et al. 2001). For example, increased growth rate in loblolly pine usually increases ring width and reduces specific gravity and most mechanical properties (Tasissa and Burkhart 1998). For diffuse porous woods, the relationship is reported to be inconsistent (Hernández et al. 1998). Figure 4 below illustrates a plot of growth rate versus (a) strength and (b) specific gravity for the woods studied here. Growth rate is defined to be the number of mm of diameter expansion per each 10 years' of growth (as shown in Table 1 above). As seen in Figure 4 below, there does not appear to be a clear relationship between growth rate and compression strength or specific gravity for the trees studied here. This result, while limited to only a few trees, is consistent with previous findings.

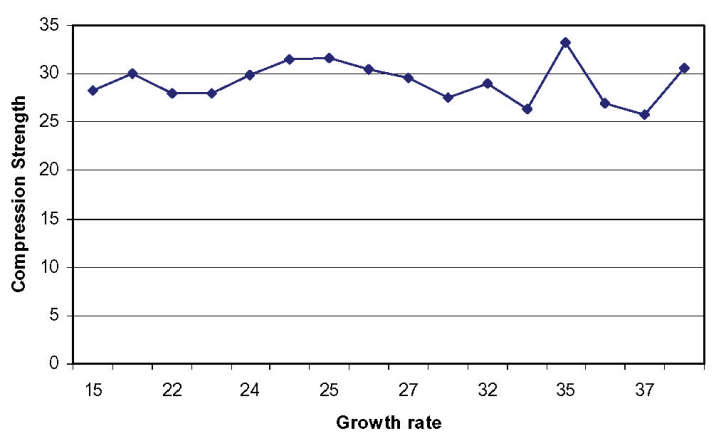

(a)

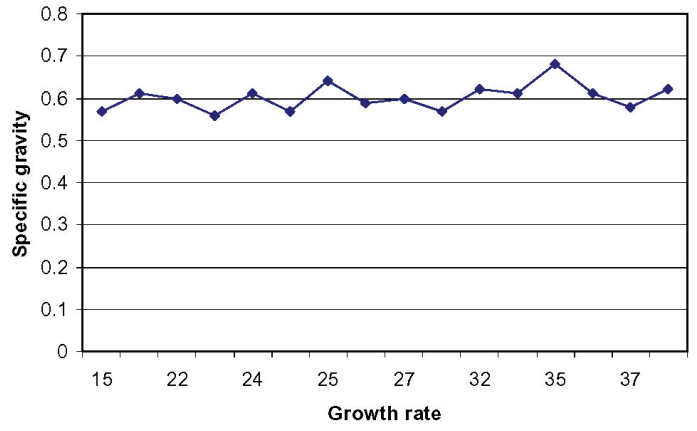

(b)

Figure 4. Influence of growth rate (defined to be $\mathrm{mm}$ of diameter expansion per 10 years' growth - seen in Table 1). (a) Compression strength for intra-ring maple specimens versus growth rate, and (b) Specific gravity versus growth rate. 
Table 4. Comparison of maximum crushing strength (MCS) from test specimens with values published in a standard handbook.

\begin{tabular}{|l|c|c|c|c|c|c|}
\hline \multirow{2}{*}{} & \multicolumn{3}{|c|}{ Intra-ring Test Specimens } & \multicolumn{3}{c|}{ Wood Handbook } \\
\cline { 2 - 7 } & [USDA FPL 1999] & $\begin{array}{c}\text { MC } \\
(\%)\end{array}$ & $\begin{array}{c}\text { MCS } \\
(\mathrm{MPa})\end{array}$ & SG & $\begin{array}{c}\text { MC } \\
(\%)\end{array}$ & $\begin{array}{c}\text { MCS } \\
(\mathrm{MPa})\end{array}$ \\
\hline Yellow-poplar & 0.44 & 12 & 33.5 & 0.42 & 12 & 38.2 \\
\hline Sweetgum & 0.48 & 12 & 39.2 & 0.52 & 12 & 43.6 \\
\hline Soft maple & 0.51 & 12 & 41.6 & 0.54 & 12 & 45.1 \\
\hline
\end{tabular}

Comparison of experimentally-determined values with standard handbook values is often useful, however not all encompassing. Table 4 above indicates values for maximum crushing strength (peak compression stress) published in the Wood Handbook [USDA FPL 1999] for standard-sized specimens [ASTM 1984] and values that were obtained from the intra-ring test specimens in this study. Notice in Table 4 that the experimentally-determined averages are near, but lower than the handbook values for all three wood types. The exact cause(s) of the difference is unknown, but there are at least two probable sources. First, a size effect is one probable cause. Figure 5 below illustrates a scanning electron micrograph of a cross-section of sweetgum and the area encompassed by several $1 \mathrm{~mm}$ x $1 \mathrm{~mm}$ squares. As mentioned, the three wood types examined in this study are diffuse porous, so there is no true, distinct earlywood or latewood region within a growth ring. However, some of the growth rings in the woods investigated exhibited fewer vessels near the terminus of some of the wider growth rings (see, for example, sweetgum in Figure 5). Because of the reduction in the number of vessels near the end of the growth ring, fibers occupy the bulk of that region. The same trend frequently occurs in the yellow-poplar specimens, and to a lesser extent, in the soft maple specimens used in this study. In the standard ASTM sized-specimens [ASTM 1984], several intact growth rings composed each test specimen and the added load carrying capacity of the fiber-rich regions contributed to the overall crushing strength. In the intra-ring specimens, the terminus regions are never intact in one individual sample and no load sharing or added load carrying capacity is provided by fiber-rich regions.

A second possible explanation is that specimen preparation created damage that would have a more significant impact on the intra-ring specimens than on standard-sized specimens. Micrographic examination of all the test specimens prior to testing has not revealed any preparation damage other than superficial tearing of cell walls. A majority of the specimen surfaces are smooth with an occasional torn cell. Nonetheless, it is still possible that small, as yet-undetected, microscopic crushing, slip planes, or internal fractures have influenced the total load carrying capacity in the intra-ring specimens. Microflaws would not be as influential in the more standard-size specimens.

Additional explanation could include reduced peak values caused by end brooming (rolling) and column buckling (bending) due to load eccentricities or material property imbalance. However, in our study any specimen that exhibited buckling, bending, or end brooming was excluded from any further analyses because these failure modes are not valid when determining maximum crushing strength.

Finally, it is important to keep in mind that a limited number of specimens has been tested to date. Additional testing and analyses will help to reveal the extent of dissimilarity between the intra-ring specimens and the more standard, full-size specimens. 


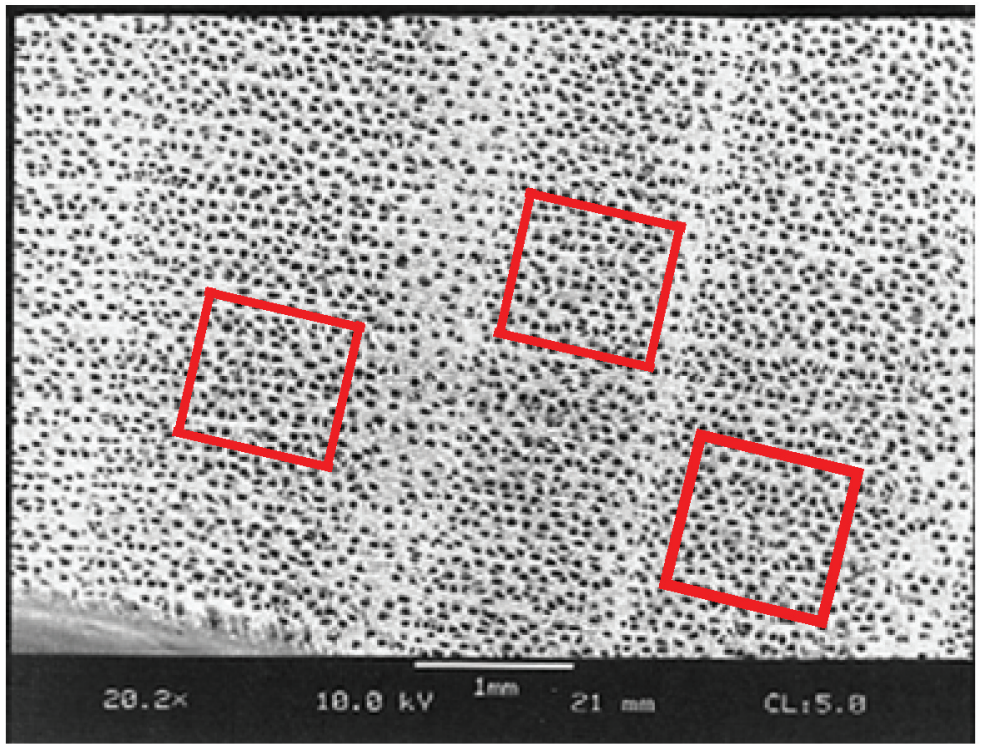

Figure 5. Scanning electron micrograph of sweetgum cross section. 20X. Squares indicate 1-mm $\mathrm{m}^{2}$ area of test specimens. SEM prepared by Carlile Price, Quantitative Wood Anatomy Lab, Virginia Tech, USA.

\section{CONCLUSIONS}

Considerable overlap in compression strength parallel to the grain was exhibited by the three wood types studied. Sweetgum values fell intermediate between yellow-poplar on the low end and soft maple on the high end, but sweetgum overlapped soft maple more than it did yellow-poplar. This indicates that sweetgum might be successfully substituted for soft maple where compression strength parallel to the grain is a consideration in product quality. Intra-ring values from 148 test specimens taken from red maple tree cores did not differ significantly amongst or between trees. Additionally, growth rate did not significantly impact compression strength or specific gravity.

\section{ACKNOWLEDGEMENTS}

Financial support from the Sustainable Engineered Materials Institute, Virginia Tech, and USDA/ CSREES Fund Number 2005-34489-16228 is gratefully acknowledged.

\section{REFERENCES}

ASTM American Society for Testing and Materials. 1984. Standard methods of testing small clear specimens of timber. D143-83. West Conshohocken, Pa.

Bendtsen, B.A.; Senft, J. 1986. Mechanical and anatomical properties in individual growth rings of plantation-grown eastern cottonwood and loblolly pine.Wood and Fiber Science 18(1):23-28.

Biblis, E.J.; Carino, H.F. 1999. Flexural properties of lumber from a 50-year old loblolly pine plantation. Wood and Fiber Science 31(2):200-203. 
Dumail, J.; Salmen, L. 2001. Intra-ring variations in the rolling shear modulus of spruce wood. Holzforschung 55(5):549-553.

Ehrnrooth, E. M. L.; Kolseth, P. 1984. The tensile testing of single wood pulp fibers in air and in water. Wood and Fiber Science 16(4): 549-566.

Fruhmann, K.; Burgert, I.; Stanzl-Tschegg, S.E.; Tschegg, E. K. 2003. Mode I Fracture behaviour on the growth ring scale and cellular level of spruce (Picea abies [L.] Karst.) and beech (Fagus sylvatica L.) loaded in the TR crack propagation system. Holzforschung 57(6):653-660.

Hernández, R.E.; Bustos, C.; Fortin, Y.; Beaulieu, J. 2001. Wood machining properties of white spruce from plantation forests. Forest Products Journal 51(6):82-88.

Hernández, R.E.; Koubaa, A.; Beaudoin, M.; Fortin, Y. 1998. Selected mechanical properties of fast-growing poplar hybrid clones. Wood and Fiber Science 30(2):138-147.

Tasissa, G; Burkhart, H.E. 1998. Modelling thinning effects on ring specific gravity of loblolly pine (Pinus taeda L.). Forest Science 44(2):212-223.

Vasic, S.; Smith, I.; Landis, E. 2002. Fracture zone characterization - Micro-mechanical study. Wood and Fiber Sci. 31(1): 42-56.

U.S. Forest Products Laboratory. 1999. Wood Handbook: Wood as an Engineering Material. USDA For. Ser. FLP-GTR-113.

Zink-Sharp, A.; Stelmokas, J.S.; Gu, H.-M. 1999. Effects of wood anatomy on the mechanical behavior of single-bolted connections. Wood and Fiber Science 31(3): 249-263.

Zink-Sharp, A; C. Price. 2004. Micromechanical Evaluation of Wood. $3^{\text {rd }}$ International Conference of the European Society for Wood Mechanics. Sept. 2004, Villa Real, Portugal, Josef Grill, Editor, pages 231-238.

Zink-Sharp, A.; Price, C.; Jeffries, T.M. 2005. Micromechanical Evaluation of Wood. in Proceedings of the 2005 Forest Products Society 59 ${ }^{\text {th }}$ International Convention June $19-22$, 2005, Quebec City, Quebec, Canada, page 33 